\title{
COUNSELING ON MENTAL HEALTH AWARENESS OF CHILDREN OF THE NATION
}

\section{Adinda Widya Isabel Lamasigi, Shafira Rahmanissa, Lovita Angeli Aprilia Iriani, Nabil Irfani Putra}

Airlangga University, Surabaya, Indonesia

Email: adinda.widya.isabel-2021@fh.unair.ac.id, shafira.rahmanissa2021@fkm.unair.ac.id, lovita.angeli.aprilia.irani-2021@fkp.unair.ac.id, nabil.fani.putra$2021 @$ fst.unair.ac.id

\begin{abstract}
Human mental health has the same position as physical health. If one's mental health is stable, their other aspects of life may function more optimally. Adolescent mental health is one of the critical factors in advancing the quality of the nation. In addition, intelligence in regulating emotions can help balance children's mental health, especially in dealing with life problems in their environment. However, the emergence of the COVID-19 pandemic, which requires adolescents to stay at home, impacts their behavior by reducing social interaction and therefore makes them experience boredom. The strategy to expand knowledge regarding mental health is first conducting research to determine what impacts are often felt by children of the nation due to mental health disorders, then providing counseling on prevention, characteristics, causes, and treatment of mental health disorders through Instagram accounts of each author. Causes and prevention of mental health disorders of children of the nation can be collected from the support of references. This condition prompted the author to carry out counseling in mental health awareness and as a forum of aspirations to expand mental health policies in Indonesia. The study results stated that two-thirds of the respondents experienced mental health disorders that may require medical attention. This becomes very dangerous for the mental health of children of the nation because it can impact children's selfdevelopment and daily life; children encounter learning difficulties because they are not able to fully concentrate on learning, behave deviantly in the school environment, thereby increasing the number of delinquency and crime in adulthood (Malfasari et al., 2020). Counseling can increase knowledge about people's mental health (Rohayati, 2021). According to the data obtained, it is currently necessary to carry out counseling to make adolescents aware of the importance of mental health and contribute to advancing the nation.
\end{abstract}

Keywords: mental health; counseling; covid-19 pandemic

Received: 2021-10-20; Accepted: 2021-11-05; Published: 2021-11-20

$\begin{array}{ll}\text { How to cite: } & \text { Lamasigi. A. W. I., et. al (2021) Counseling on Mental Health Awareness of Children of The Nation, } 6 \text { (2), } \\ & \text { Syntax Literate: Jurnal Ilmiah Indonesia } \\ \text { E-ISSN: } & 2548-1398 \\ \text { Published by: } & \text { Ridwan Institute }\end{array}$


Adinda Widya Isabel Lamasigi, Shafira Rahmanissa, Lovita Angeli Aprilia Iriani, Nabil Irfani Putra

\section{Introduction}

The World Health Organization (WHO) revealed that 1 billion people live with mental disorders (Muhammad Najmi Hafiy and Unike Khaerani Salmayanti, 2021). From statistical data released by WHO (2012), it is recorded that 450 million people worldwide suffer from mental health problems and one-third of these data occurred in developing countries (Pebrianti, 2021). Furthermore, according to the WHO (2020) study, about $83 \%$ of 130 countries decided to include mental health in their plans to deal with the COVID-19 pandemic (Masyah, 2020). Mental disorders can become which is a severe disease and will burden the world's top health global problems in the next 2030 (Rahmawati et al., 2021). The governments focus on handling the COVID-19 pandemic to the point of not paying attention to the psychosocial conditions of the public that individuals have been born as one of the impacts of the pandemic. The mental health problems that arise due to the COVID-19 pandemic can turn into long-term health problems. The WHO has imposed a public health emergency status, such as carrying out social restrictions and self-isolation or quarantine, which is a factor in public mental health disorders (Ridlo, 2020).

According to WHO, the emergence of stress during the COVID-19 pandemic is in the form of fear and anxiety about the health condition of oneself and others who are being looked after, Significant changes in sleep patterns and/or eating patterns, difficulty in concentrating and sleeping, and the severity of a person's physical condition who have suffered from chronic illness and/or psychological disorders (Iqbal \& Rizqulloh, 2020). A high sense of loneliness and lack of social interaction can be factors in mental disorders such as schizophrenia and major depression. The emergence of anxiety about the health status of family members and uncertainty about what will happen in the future is thought to increase fear, anxiety, and depression (Pandemi Dan Mental Health: Meringkas Isu Kesehatan Mental Selama Satu Tahun Di Era Pandemi, 2020).

Mental health is used as a criterion of public welfare (Wijaya, 2019). Therefore, it is vital to preserving it in order to maintain the public's welfare. This mental health problem still requires more attention and support, such as from family, community, and institutions (Bintang \& Mandagi, 2021). However, many people do not know that mental health has the same importance as physical health. Indirectly, whether or not one's mental health can affect physical health.

Viewed from physical health, mental health is an integral component. Directly or indirectly, mental and physical health must be interconnected. Each stage of development requires stable mental health through a healthy soul, especially for adolescents who are still experiencing obstacles (Fatimah \& Dewi Aisyah, 2021). A healthy soul is able to influence how we think, feel and behave. We must realize that mental and mental health is the main thing and cannot be ruled out. Good mental health can provide an opportunity for individuals to realize their potential, overcome various problems of normal life, work actively, be productive, and make a real contribution to 
the community they live in (Nasrullah \& Sulaiman, 2021). During this pandemic, mental health problem, such as anxiety and depression, can occur (Levani, 2020).

In everyday life, humans are not free from stress. Stress is a normal physical and psychological response to the many problems that plague life, which is constantly changing and never-ending. Everyone can experience this stress. Especially during the current pandemic where everyone's movement is limited, it is advised to stay at home. Daily activities that are carried out continuously and lack of variation can make people feel bored. People who usually hang out, socialize with people, are busy, and do different activities now have to adapt to activities at home by utilizing increasingly sophisticated technology. Because of boredom, there are worrying impacts, namely a decrease in the welfare and level of happiness of adolescents and even an increase in violence against children by parents (Yafi Sabila Rosyad, Setya Retno Wulandari, Istichomah \& Anisa Febristi, 2021).

When one has a healthy mentality, of course, there are factors that affect that mentality. There are two mental health factors, namely internal and external factors. These internal factors include personality, physical condition, development and maturity of thought patterns, psychological conditions, religiosity, attitude towards life problems, the meaning of life, and harmony of thought. External factors include social, political, economic, customary, environmental conditions, and so on (Athiyyah \& Santoso, 2021).

However, this raises a new problem where many people, including students, are starting to get depressed by the news that the pandemic will never end, the ineffective teaching system, or other problems such as network problems. This external pressure has more or less affected the mental health of the students. According to the analysis, excessive worry can affect one's psyche or is commonly referred to as stress. So from these things, it is necessary to observe the current mental health conditions of children of the nation, especially during the current pandemic and social restrictions, which also affect the mental health of adolescents and/or youth.

Despite being important, there is a lack of community movement to reduce risks to mental health. Most adolescents complain about the presence of Covid-19 and become a motive for stress and then irrational acts (Sekar et al., 2020). However, mental health disorders should be prevented earlier before they become serious illnesses that are difficult to treat/cure. Therefore, we hold mental health counseling for children of the nation, which can prevent and/or reduce mental health disorders in students. The community and the equipment and health workers have an essential role in overcoming mental disorders in the community (Maulana et al., 2019).

The principles of mental health are as follows: being kind to oneself, being able to balance oneself, being self-actualized, being able to accept others, socializing and adapting to the environment, having a sense of interest in tasks and work, being religious, planning a life with visions, has rules for oneself, be responsible and honest (Desti Azania, 2021). Children and adolescents who can practice worship, overcome problems, increase gratitude, are able to adapt, maintain good relations with others and 

Irfani Putra

their God are signs that these children and adolescents have good mental health (Fatimah \& Dewi Aisyah, 2021).

With the counseling on mental health awareness of children of the nation, it is expected that the health problems of children of the nation will improve so that they can carry out activities without these health problems. It is also expected to prevent serious health diseases in children of the nation.

\section{Research Methods}

The research model chosen by the author in compiling this article is a quantitative research method with polling or questionnaire research instruments and an approach to literature study through various available data and information sources. In a journal written by Ahmad Rijali, explained that a Literature Study is a method of conducting research using written sources in books, magazines, articles, and journals according to the discussion (Rijali, 2019). The authors used similar research data, mental health data by (Basic Health Research) Riskesdas. Other data mentioned in the journal have written sources that are published and can be accessed freely and openly. The implementation of this research includes data analysis and opinions regarding the results of data analysis that has been obtained because this study aimed to find out and realize how important the mental health of children of the nation is.

The authors review that the research targets are children of the nation, especially adolescents aged 15-21 years undergoing lectures, schools, especially high school, and working online and offline, and actively using Instagram. After collecting data and sources of information, the researchers reviewed the data and information by determining the research subject. The research subject is the result of a framework regarding where the data or research variables are found or where the object of research can be found.

The research subject determined in this observation is Instagram and an instrument in the research, through several measuring tools to achieve education about children's mental and emotional health. With the allegation that the mental health condition of children is not sufficiently known to themselves and the surrounding environment. Then the measuring instrument used is the results of data analysis based on the results of respondents answers with predetermined criteria. Where the questionnaire in the form of a poll with a list of questions to determine the mental health of children of the nation is structured in the form of multiple-choice questions and open questions, which are, of course, easy questions so that respondents do not confuse and remain relaxed when answering the questionnaire.

The results that have been obtained will be continued by presenting the data in tabular form in order to show precise results and easier to analyze. This data processing activity will be made by comparing the presentation results on the poll and the respondents who participated in the questionnaire. 


\section{Data Results}

\section{Table 1}

Distribution of the frequency of sudden changes in mood or emotion in the past of respondents from Instagram followers of chairman and members

\begin{tabular}{lll}
\hline \multicolumn{1}{c}{$\begin{array}{l}\text { Mood } \\
\text { Changes }\end{array}$} & Frequency & $\begin{array}{l}\text { Percentage } \\
(\boldsymbol{\%})\end{array}$ \\
\hline $\begin{array}{l}\text { Sudden Mood } \\
\text { Changes }\end{array}$ & 276 & 90,5 \\
\hline Normal Mood & 29 & \\
\hline Total & 305 & 9,5 \\
\hline
\end{tabular}

The data obtained was converted into a table, namely table 1, which shows the 305 respondents who follow Instagram accounts of chairman and members. Most of the respondents, namely 276 people $(90.5 \%)$, experienced sudden changes in mood or emotions. Furthermore, as many as 29 people (9.5\%) did not experience sudden changes in mood or emotions but some experienced other mental disorders.

Table 2

Distribution of the frequency of occurrence of panic and excessive fear of respondents from Instagram followers of chairman and members

\begin{tabular}{lll}
\hline $\begin{array}{c}\text { Panick and Excessive } \\
\text { Fear }\end{array}$ & Frequency & Percentage (\%) \\
\hline Experienced & 227 & 74,43 \\
\hline Did Not Experience & 78 & 25,57 \\
\hline \multicolumn{1}{c}{ Total } & 305 & 100,0 \\
\hline
\end{tabular}

The data obtained was converted into a table, namely table 2, which shows the 305 respondents who follow Instagram accounts of chairman and members. Most of the respondents, namely 227 people (74.43\%), experienced excessive panic and fear, and as many as 78 people $(25.57 \%)$ did not experience panic and excessive fear but some experienced other mental disorders.

Table 3

Distribution of the frequency of stress in doing online activities due to the pandemic experienced by respondents from Instagram followers of chairman and members

\begin{tabular}{ccc}
\hline Stress & Frequency & Percentage (\%) \\
\hline Experienced & 263 & 86,3 \\
\hline Did Not Experience & 42 & 13,7 \\
\hline Total & 305 & 100,0 \\
\hline
\end{tabular}


Adinda Widya Isabel Lamasigi, Shafira Rahmanissa, Lovita Angeli Aprilia Iriani, Nabil Irfani Putra

The data obtained was converted into a table, namely table 3 , which shows the 305 respondents who follow Instagram accounts of chairman and members. Most of the respondents, namely 263 people $(86.3 \%)$, experienced stress during online activities due to the pandemic, and as many as 42 people (13.7\%) did not experience the stress of conducting online activities due to the pandemic but some experienced other mental disorders.

\section{Discussion}

\section{A. General condition of respondents}

Based on the analysis of poll data conducted, it is known that emotional control is a serious problem for respondents. This is in accordance with the opinion of Shinta Mutiara Puspita (Puspita, 2019) in her research journal, which revealed that emotional management still cannot be controlled by everyone, especially teenagers. This needs to concern parties personally related to each teenager, family, or other people around, with positive approaches as religious people (Kardiatun et al., 2019). Knowing yourself well will bring you to be a superior you by faster recovery from sadness, adversity, and other feelings of hopelessness to face life (Munir \& Herianto, 2020).

\section{B. Problems and Handling}

Based on the question instrument that has been made, several conditions were selected, which according to the author, are problems that the respondents quite commonly know. The first point is mood changes. Based on functional studies of the body or physiology, it is known that the mood changes experienced by teenagers are more experienced by young women due to the menstrual cycle, which is related to the hormone cycle (Nurul Anjarsari \& Etika Purnama Sari, 2020). In handling the problem, most teens with mood swings that are going on will cope on their own. However, it would be better to channel the emotions felt in mood changes properly and wisely through parental assistance (Nurul Anjarsari and Etika Purnama Sari, 2020).

Then the problem of anxiety with excessive panic and fear. Some teenagers with these feelings are known to come from accepting a bad environment for themselves. The construction of a society with different acceptances for these physical conditions is often associated with anxiety, fear, or panic behavior that makes adolescents take actions such as escape or avoidance that drastically limit their mobility and regional autonomy (Thaariq, 2019). The result is also very fatal. Some examples of cases will lead teenagers to make bold decisions about bad things. Loneliness is also a factor because there is a close relationship between loneliness and anxiety experienced by adolescents and is a positive relationship, where a positive or unidirectional relationship in question indicates that an increase will follow the increased intensity of loneliness in anxiety in adolescents (Lukis Gatra Siwi \& Mochammad Bagus Qomaruddin, 2021). Anxiety is often characterized by excessive fear or worry for a long time. If anxiety lasts continuously, it can be very tiring and even death (Hendrawati et al., 2021). 
Then stress conditions, stress is a depressed condition due to pressure on a person, assessing the implementation of research amid the covid pandemic can be real pressure for teenagers (Gani Apriningtyas Budiyati \& Eka Oktavianto, 2020). Having a burden at certain times where mental readiness and knowledge of how to deal with those who are less able to make a person experience stress (Dwi Ananda \& Apsari, 2020). Working at home can increase loneliness because social interactions with coworkers are limited (Trisnasari \& Wicaksono, 2021) and emerge confusion about sharing stories. Lonely individuals can make a deviation of thoughts from themselves to others (Meilia, 2021) Hidden problems will make the individual ill and experience significant mood changes (Aziz et al., 2021) Sharing problems may not be the answer for every individual. Some of them are only able to hide and erase before the surrounding environment is known. However, some of them can also cause a depressed state to become more protracted. The solution that can be offered is by communicating with oneself to understand yourself and know how to handle the most appropriate for yourself (Zikry et al., 2020). This is the first step you can try.

To this day, there is no accurate information about how long the COVID-19 situation will last. If we can accept the current conditions, which are not normal, then we are quite ready to adapt. The result of success from adapting, namely giving birth to resilience in a person (Vibriyanti, 2020).

\section{Conclusions}

COVID-19 pandemic has caused many negative impacts on society, especially children of the nation, the majority of whom experience various symptoms on their mental health (Lempang et al., 2021). Experts in this field can only diagnose mental health disorders. Therefore, if teenagers feel they have excessive emotional disturbances, it is highly recommended to consult an expert, but before that, getting acceptance from people around is very much needed as support for teenagers. As can be seen, adolescence is a condition of the most active growth and development, so rapid changes become something that must be recognized quickly as well. This can be a problem if self-acceptance and understanding from a more mature person are not maximized.

Teenagers are advised to know themselves well; this can be done if they get full assistance from parents or the right adult figure to share experiences. In addition, the environment in which adolescents grow and develop is also an external factor that influences the emotional development of adolescents. The environment becomes a big part that builds the emotional development of adolescents. Doing hobbies as entertainment from the busyness and daily thoughts that accumulate is also essential because hobbies help improve mood and self-positivity (Nasya Salsabila, 2021). There may be some suggestions for the family or the environment where the child lives, namely creating a clean, healthy home environment, physically and psychologically, which is expected to reduce stress (Fauziyyah et al., 2021). The government also reduces the number of mental and mental health disorders with the Indonesian 
Adinda Widya Isabel Lamasigi, Shafira Rahmanissa, Lovita Angeli Aprilia Iriani, Nabil Irfani Putra

Psychological Association (HIMPSI), which launched a mental health psychology consultation service. This service aims to help deal with the potential for psychological pressure from the community during the Covid-19 pandemic (Winurini, 2020). The provision of information and knowledge about mental health that can affect adolescents' ability is expected to be able to deal with mental health disorders (Rozali et al., 2021). Institutions that have the authority should provide preventive measures to eradicate mental health problems (Setyaningrum \& Yanuarita, 2020). 


\section{BIBLIOGRAFI}

Athiyyah, \& Santoso, H. (2021). Permasalahan Kesehatan Mental di Masa Covid-19. Jurnal Riset Dan Pengabdian Masyarakat, 1(2), 170-185. https://doi.org/10.22373/jrpm.v1i2.634 Google Scholar

Aziz, Z. A., Ayu, D. A., Bancin, F. M., Syara, S. G., Manalu, W. B., S, R. A., Lia, S. F., Tanjung, L. P., Boang manalu, A. S., Br Karo, S. indah K., Br Bangun, C. A., Limbong, F. W., \& Siregar, N. F. (2021). Gambaran Kesehatan Mental Mahasiswa di Masa Pandemi Covid-19. Jurnal Dunia Kesmas, 10(1), 130-135. https://doi.org/10.33024/jdk.v10i1.3256 Google Scholar

Bintang, A. Z., \& Mandagi, A. M. (2021). Kejadian Depresi pada Remaja Menurut Dukungan Sosial di Kabupaten Jember. Journal of Community Mental Health and Public Policy, 3(2), 92-101. https://doi.org/10.51602/cmhp.v3i2.55 Google Scholar

Desti Azania. (2021). Peran Spirtual bagi Kesehatan Mental Mahasiswa di Tengah Pandemi Covid-19. Humanistika: Jurnal Keislaman, 7(1), 1-20. Google Scholar

Dwi Ananda, S. S., \& Apsari, N. C. (2020). Mengatasi Stress pada Remaja saat Pandemi Covid-19 dengan Teknik Self Talk. Prosiding Penelitian Dan Pengabdian Kepada Masyarakat, 7(2), 248-256. https://doi.org/10.24198/jppm.v7i2.29050 Google Scholar

Fatimah K and Dewi Aisyah. (2021). Peningkatan Kesehatan Mental Anak dan Remaja Melalui Ibadah Keislaman. Al-Isyrof: Jurnal Bimbingan Konseling Islam, 3(1), 17. https://doi.org/10.51339/isyrof.v3i1.292 Google Scholar

Fauziyyah, R., Awinda, R. C., \& Besral, B. (2021). Dampak Pembelajaran Jarak Jauh terhadap Tingkat Stres dan Kecemasan Mahasiswa selama Pandemi Covid-19. Jurnal Biostatistik, Kependudukan, Dan Informatika Kesehatan, 1(2), 113-123. https://doi.org/10.51181/bikfokes.v1i2.4656 Google Scholar

Gani Apriningtyas Budiyati and Eka Oktavianto, \& Jurusan. (2020). Stres dan Resiliensi Remaja di Masa Pandemi Covid-19. Husada Mahakam: Jurnal Kesehatan, 10(2), 11-18. Google Scholar

Hendrawati, Sriati, A., \& DA, iceu A. (2021). Stress, Kecemasan, dan Depresi pada Pengunjung Care Free Day di Kabupaten Garut. Jurnal Ilmu Keperawatan, 21(1), 29-42. https://www.ejurnal.stikesbth.ac.id/index.php/P3M_JKBTH/article/view/678 Google Scholar

Iqbal, M., \& Rizqulloh, L. (2020). Deteksi Dini Kesehatan Mental akibat Pandemi Covid-19 pada Unnes Sex Care Community melalui Metode Self Reporting Questionnaire. Praxis, 3(1), 20-24. https://doi.org/10.24167/praxis.v3i1.2730 Google Scholar 
Adinda Widya Isabel Lamasigi, Shafira Rahmanissa, Lovita Angeli Aprilia Iriani, Nabil Irfani Putra

Kardiatun, T., Bhakti, W. K., Ramadhaniyati, R., Ariyanti, S., \& Wahyuni, T. (2019). Penyuluhan Kesehatan Tentang Kesehatan Jiwa Usia Muda (Remaja) Pendekatan Keluarga dan Agama sebagai Preventif Psychosocial Trauma. Celebes Abdimas: Jurnal Pengabdian Kepada Masyarakat, 1(2), 90-95. https://doi.org/10.37541/celebesabdimas.v1i2.213 Google Scholar

Lempang, G. F., Walenta, W., Rahma, K. A., Retalista, N., Maluegha, F. J., \& Utomo, F. I. P. (2021). Depresi Menghadapi Pandemi Covid-19 pada Masyarakat Perkotaan (Studi Literatur). Pamator Journal, 14(1), 66-71. https://doi.org/10.21107/pamator.v14i1.9854 Google Scholar

Levani, et al. (2020). Stress dan Kesehatan Mental di Masa Pandemi Covid-19. Seminar Online Update on COVID-19 Multidiciplinary Perspective, 134-144. Google Scholar

Lukis Gatra Siwi and Mochammad Bagus Qomaruddin. (2021). Perasaan Kesepian Berhubungan dengan Depresi, Kecemasan dan Stres pada Siswa SMA. Jurnal Ilmiah Permas: Jurnal Ilmiah STIKES Kendal, 11(4), 757-770. Google Scholar

Malfasari, E., Febtrina, R., Herniyanti, R., Timur, L. B., Sekaki, P., Tim, L. B., Kota, P., \& Pekanbaru, K. (2020). Kondisi Mental Emosional pada Remaja. Jurnal Keperawatan Jiwa, 8(3), 241-246. Google Scholar

Masyah, B. (2020). Pandemi Covid 19 terhadap Kesehatan Mental dan Psikososial. Mahakam Noursing, 2(8), 353-362. http://ejournalperawat.poltekkeskaltim.ac.id/index.php/nursing/article/view/180/74 Google Scholar

Maulana, I., S, S., Sriati, A., Sutini, T., Widianti, E., Rafiah, I., Hidayati, N. O., Hernawati, T., Yosep, I., H, H., Amira D.A, I., \& Senjaya, S. (2019). Penyuluhan Kesehatan Jiwa untuk Meningkatkan Pengetahuan Masyarakat tentang Masalah Kesehatan Jiwa di Lingkungan Sekitarnya. Media Karya Kesehatan, 2(2), 218225. https://doi.org/10.24198/mkk.v2i2.22175 Google Scholar

Meilia, A. (2021). Pengaruh Kesepian sebagai Salah Satu Faktor Risiko Pengalaman Psikotik pada Dewasa Awal. Buletin Riset Psikologi Dan Kesehatan Mental, 1(2), 1207-1217. Google Scholar

Muhammad Najmi Hafiy and Unike Khaerani Salmayanti. (2021). Pentingnya Menjaga Kesehatan Mental bagi Remaja. In Gama Cendekia (pp. 1-5). https://gc.ukm.ugm.ac.id/2021/05/pentingnya-menjaga-kesehatan-mental-bagimahasiswa/ Google Scholar

Munir, M. B., \& Herianto, H. (2020). Tingkat Pemahaman Moderasi Beragama serta Korelasinya terhadap Pengaruh Kesehatan Mental, Keaktifan Berorganisasi dan Prestasi Akademik. Prosiding Nasional, 3, 137-150. http://prosiding.iainkediri.ac.id/index.php/pascasarjana/article/view/46 Google Scholar 
Nasrullah, \& Sulaiman, L. (2021). Analisis Pengaruh Covid-19 terhadap Kesehatan Mental Masyarakat di Indonesia. Media Kesehatan Masyarakat Indonesia, 20(3), 206-211. https://doi.org/10.14710/mkmi.20.3.206-211 Google Scholar

Nasya Salsabila. (2021). Menjaga Kesehatan Mental di Masa Pandemi. In PsyArXiv Preprints (pp. 1-4). https://doi.org/10.31234/osf.io/rd4zf Google Scholar

Nurul Anjarsari and Etika Purnama Sari. (2020). Relationship Stress Levels with Menstrual Cycle in Adolescent Girls. Jurnal Keperawatan Jiwa, 2(1), 1-4. Google Scholar

Pandemi dan Mental Health: Meringkas Isu Kesehatan Mental selama Satu Tahun di Era Pandemi. (2020). BEM KM FKG UGM. https://bem.fkg.ugm.ac.id/2021/01/10/kajian-pandemi-dan-mental-health/ Google Scholar

Pebrianti, D. K. (2021). Pentingnya Menjaga Kesehatan Jiwa saat Pandemi Covid-19 Kesehatan jiwa. Jurnal Abdimas Kesehatan (JAK), 3(2), 178-184. http://jak.stikba.ac.id/index.php/jak/article/view/221/128 Google Scholar

Puspita, S. M. (2019). Kemampuan Mengelola Emosi sebagai Dasar Kesehatan Mental Anak Usia Dini. SELING: Jurnal Program Studi PGRA, 5(1), 85-92. http://jurnal.stitnualhikmah.ac.id/index.php/seling/article/view/434 Google Scholar

Rahmawati, N. A., Karimah, A., \& Amin, M. M. (2021). Inflammation in Depression. Jurnal Psikiatri Surabaya, 10(2), 50-56. https://doi.org/10.20473/jps.v10i2.22045 Google Scholar

Ridlo, I. A. (2020). Jurnal Psikologi dan Kesehatan Mental Pandemi COVID-19 dan Tantangan Kebijakan Kesehatan Mental di Indonesia. Departemen Administrasi Dan Kebijakan Kesehatan, Fakultas Kesehatan Masyarakat Universitas Airlangga, 155-164. https://doi.org/10.20473/jpkm.v5i12020.155-164 Google Scholar

Rijali, A. (2019). Qualitative Data Analysis. Alhadharah: Jurnal Ilmu Dakwah, 17(33), 81-95. Google Scholar

Rohayati, N. (2021). Peberdayaan Masyarakat melalui Penyuluhan Kesehatan Mental sebagai Upaya Peningkatan Kesehatan Mental Masyarakat Desa Srikamulyan. Prosiding Konferensi Nasional Penelitian Dan Pengabdian Universitas Buana Perjuangan Karawang, 1671-1678. https://journal.ubpkarawang.ac.id/index.php/ProsidingKNPP/article/view/1703 Google Scholar

Rozali, Y. A., Sitasari, N. W., \& Lenggogeni, A. (2021). Meningkatkan Kesehatan Mental di Masa Pandemi. Jurnal Pengabdian Masyarakat AbdiMas, 7(2), 109-113. https://doi.org/10.47007/abd.v7i2.3958 Google Scholar

Sekar, S., Ananda, D., \& Apsari, N. C. (2020). Mengatasi Stress Pada Remaja Saat 
Adinda Widya Isabel Lamasigi, Shafira Rahmanissa, Lovita Angeli Aprilia Iriani, Nabil Irfani Putra

Pandemi Covid-19. 7(2), 248-256. Google Scholar

Setyaningrum, W., \& Yanuarita, H. A. (2020). Pengaruh Covid-19 terhadap Kesehatan Mental Masyarakat di Kota Malang. JISIP (Jurnal Ilmu Sosial Dan Pendidikan), 4(4), 550-556. https://doi.org/10.36312/jisip.v4i4.1580 Google Scholar

Thaariq, Z. Z. A. (2019). Pengaruh Nomophobia Terhadap Agoraphobia dalam Upaya Mengantisipasi Gangguan Kesehatan Mental pada Remaja. Academia. https://www.academia.edu/42864528/Pengaruh_Nomophobia_Terhadap_Agoraph obia_Dalam_Upaya_Mengantisipasi_Gangguan_Kesehatan_Mental_Pada_Remaja Google Scholar

Trisnasari, S. A. Y. U., \& Wicaksono, D. A. (2021). Pengaruh Loneliness terhadap Job Stress Pekerja Work from Home ( WFH ) pada Masa Pandemi Covid-19. Buletin Riset Psikologi Dan Kesehatan Mental, 1(2), 1218-1226. Google Scholar

Vibriyanti, D. (2020). Kesehatan Mental Masyarakat: Mengelola Kecemasan di Tengah Pandemi Covid-19. Jurnal Kependudukan Indonesia, 69-74. https://doi.org/10.14203/jki.v0i0.550 Google Scholar

Wijaya, Y. D. (2019). Kesehatan Mental di Indonesia: Kini dan Nanti. Buletin Jagaddhita, 1(1), 1-4. Google Scholar

Winurini, S. (2020). Permasalahan Kesehatan Mental akibat Pandemi COVID-19. Info Singkat: Kajian Singkat Terhadap Isu Aktual Dan Strategis, 12(15), 13-18. Google Scholar

Yafi Sabila Rosyad, Setya Retno Wulandari, Istichomah, R. M., \& Anisa Febristi, D. M. S. \& A. D. C. D. (2021). Dampak Pandemi Covid-19 terhadap Kesehatan Mental Orang Tua dan Anak. Jurnal Ilmiah Kesehatan Keperawatan, 17(1), 42-47. https://doi.org/10.26753/jikk.v17i1.530 Google Scholar

Zikry, A., Mentari, B., Liana, E., \& Pristya, T. Y. R. (2020). Most Effective Stress Management Techniques in Adolescents: Literature Review. Jurnal Ilmiah Kesehatan Masyarakat, 12(4), 191-196. Google Scholar

\section{Copyright holder:}

Adinda Widya Isabel Lamasigi, Shafira Rahmanissa, Lovita Angeli Aprilia Iriani, Nabil Irfani Putra (2021)

First publication right:

Syntax Literate: Jurnal Ilmiah Indonesia

This article is licensed under: 